\title{
Root Rot Disease Incited by Macrophomina phaseolina in Arid Legumes and their Management: A Review
}

Mahabeer Singh, Jitendra Singh, Shivam Maurya,

Sunil Kumar, A.K. Meena, Pinki Sharma, Lalita Lakhran

10.18805/LR-4714

\begin{abstract}
Macrophomina phaseolina (Tassi) Goid. is a soil- and seed-borne pathogen that causes charcoal rot and various rots and blights of more than 500 crop species. Dry root rot (DRR) also called as charcoal rot which causes yield loss ranged from 25-48 per cent. The pathogen is necrotroph and infects a wide range of crops. It is observed that mycelium of $M$. phaseolina in cotyledons, plumule and radicle, in the naturally infected seeds of mungbean and cowpea. The disease symptoms are clearly visible from the time of emergence and can be evaluated at various stages of development of the plant. The mechanical plugging of the xylem vessels by microsclerotia, toxin production, enzymatic action and mechanical pressure during penetration lead to disease development. Management of $M$. phaseolina aim to reduce the number of sclerotia in soil or to minimize the contact of the inoculum and the host. Soil solarization can be a cost-effective method for management of soil borne diseases. Disease suppression by biocontrol agents such as Trichoderma harzianum, T. viride and Bacillus subtilis are the sustained manifestation of interactions among the plant, the pathogen, the biocontrol agent, the microbial community on and around the plant and the physical environment and considerably inhibited growth of $M$. phaseolina. Essential oils and plant extracts contain a multitude of bioactive substances against fungi, bacteria and nematodes. It has been reported that neem oil, turmeric and garlic was effective against $M$. phaseolina in in vitro condition. Chemical control is an effective method when seed treatment and foliar spray of carbendazim, topsin M-70, captan, thiram, mancozeb, copper oxychloride against root rot and leaf blight (Macrophomina phaseolina) topsin M-70, captan, thiram, mancozeb, copper oxychloride against root rot (Macrophomina phaseolina). As non-chemical alternative methods can be time-consuming and less effective against soilborne plant pathogens. Chemical control is an effective method of controlling some soilborne diseases in agricultural crops. Varoius workers are reported compatibility of biocontrol agents with fungicides and found that Carbendazim and biocontrol agents Trichoderma viride, T. harizianum were found effective under in vitro and pot condition.
\end{abstract}

Key words: Disease, Macrophomina phaseolina, Microsclerotia, Necrotroph, Phaseolinone.

Macrophomina phaseolina (Tassi) Goid. is a soil- and seedborne polyphagous pathogen that causes charcoal rot and various rots and blights of more than 500 crop species. Dry root rot (DRR) also called as charcoal rot which causes yield loss ranged from 25-48 per cent (lqbal and Mukhtar, 2014). The pathogen is necrotroph and infects a wide range of crops. Roots of infected plants rot, plants wilt and ultimately die when the disease reach at advance stages (Khan et al., 2017). In South and Southeast Asia, Macrophomina species causes diseases in diverse field crops, including common bean, (Phaseolus vulgaris L.), cowpea [Vigna unguiculata (L.), Walp], urdbean [V. mungo (L.) Hepper], soybean [Glycine max (L.) Merr.], potato (Solanum tuberosum L.) and cotton (Gossypium hirsutum L.) (Suriachandraselvan et al., 2005). During infection on host plants the fungus produces several cell wall-degrading enzymes, hydrolytic enzymes and phytotoxins such as phaseolinone and botryodiplodin (Ramezani, 2008). Both morphological examination and molecular techniques were used to characterize isolates of $M$. phaseolina isolated from diverse legume crops. Identification of $M$. haseolina based on cultural and morphological features such as colony morphology, microscopic examination of microsclerotia, pycnidia and conidia are not sufficient (Saleh et al., 2010).
Department of Plant Pathology, SKN College of Agriculture, SKN Agriculture University, Jobner-303 329, Rajasthan, India.

Corresponding Author: Mahabeer Singh, Department of Plant Pathology, SKN College of Agriculture, SKN Agriculture University, Jobner-303 329, Rajasthan, India. Email: mahaveer.ppath@sknau.ac.in

How to cite this article: Singh, M., Singh, J., Maurya, S., Kumar, S., Meena, A.K., Sharma, P. and Lakhran, L. (2021). Root Rot Disease Incited by Macrophomina phaseolina in Arid Legumes and their Management: A Review. Legume Research. DOI: 10.18805/ LR-4714.

Submitted: 30-06-2021 Accepted: 13-09-2021 Online: 09-11-2021

Molecular methods such as RAPD analysis (Fuhlbohm et al., 2013), use of species-specific primers, LAMP (loopmediated isothermal amplification)-based detection, sequencing of conserved gene and internal transcribed spacers (ITS) of 18S rRNA (Ghosh et al., 2017) are commonly used to identify fungal pathogens. In addition, multilocus sequence analysis of housekeeping genes (such as calmodulin, histone $\mathrm{H} 3$ and translation elongation factor 1 -alpha genes) is also being used to identify and characterize fungal plant pathogens (lqbal and Mukhtar, 2014). The management of DRR of mungbean is challenging 
as the causal agent is a soil- and seed-borne pathogen. Chemical control of the soil- borne fungus is difficult and not economical for small holder farmers. The use of biocontrol agents and botanical extracts in combination with chemical fungicides provided good control of DRR of mungbean under controlled environments (Sundaramoorthy et al., 2013). However, these biocontrol products are not commercially available and also require further evaluation in fields. If available, use of host resistance would be one of the best options to manage DRR of mungbean (Fuhlbohm et al., 2013).

\section{Taxonomy and nomenclature}

Macrophomina phaseolina (Tassi) Goid. [= Tiarosporella phaseolina (Tassi) Van der Aa] is a soil borne plant pathogenic fungus. It belongs to the anamorphic Ascomycetes and is characterized by the production of both pycnidia and sclerotia in host tissues and culture media. The pycnidial state was initially named Macrophoma phaseolina by Tassi in 1901. Goidanich (1947) proposed Macrophomina phaseolina. Tiarosporella phaseolina (Tassi) Van der Aa was used in 1981 by Van der Aa to designate the species. The sclerotial state was described for the first time by Halsted as Rhizoctonia bataticola (Taub.) Butler on Ipomoea batatas in 1890. Same fungus was isolated from cowpea in India in 1912 by Shaw and was then named Sclerotium bataticola. The authors pointed out the differences between Tiarosporella and Macrophomina, which produces in the pycnidia percurrently proliferating conidiogenous cells. The pycnidiospores are ellipsoid to obovoid and measure 20-24×7-9 $\mu \mathrm{m}$. During the sclerotial formation, 50-200 individual hyphal cells aggregate to give multicellular bodies named microsclerotia. The microsclerotia are black and are variable in size (50-150 $\mu \mathrm{m})$ depending on the available nutrients of the substrate on which the propagules are produced. Isolates with fast mycelial growth and abundant sclerotial production were more pathogenic on clusterbean (Cyamopsis tetragonoloba) seedlings than isolates growing more slowly (Purkayastha et al., 2004). Color of cultures on PDA, ability to sporulate in infected host plants and pycnidial size also have been reported to vary greatly. Isolates of $M$. phaseolina obtained from resistant sorghum genotypes were more pathogenic on susceptible sorghum than two other isolates originally obtained from susceptible sorghum genotypes (Diourte et al., 1995). M. phaseolina is a heterogeneous species that cannot be partitioned into distinct subspecies groups based on pathogenicity, pycnidium production and chlorate utilization. Although pointed out that host specialization in M. phaseolina occurs with maize, no clear evidence for the occurrence of formae speciales, subspecies or physiological races have been reported so far. Various recent studies were devoted to the genetic and pathogenic variability of M. phaseolina. Significant advances in molecular detection and differentiation of $M$. phaseolina isolates have been achieved using restriction fragment length polymorphism
(RFLP), random amplified polymorphic DNA (RAPD) and Amplified Fragment Length Polymorphism (AFLP) analysis (Reyes-Franco et al., 2006). So far, none of these methods have however been able to differentiate isolates of $M$. phaseolina from specific hosts or geographic locations. The lack of a strong correlation between genotype and geographical origin suggests a high diversity level within and among the population of M. phaseolina (Jana et al., 2005). Nevertheless, developed a single RAPD primer OPA-13 that distinguishes isolates of $M$. phaseolina from soybean, sesame, groundnut, chickpea, cotton, common bean, okra and 13 other hosts.

\section{Variability in pathogen population}

Much work has been done to elucidate the variability in morphology, physiology, pathogenicity and genotype of $M$. phaseolina. Variation in cultural characteristics and virulence to soybean has been reported in the U.S. Cultural characteristics and growth rates of 8 different jute isolates of $M$. phaseolina appeared to be related to their pathogenicity. Isolates with fast mycelial growth and abundant sclerotial production were more pathogenic on clusterbean (Cyamopsis tetragonoloba) seedlings than isolates growing more slowly (Purkayastha et al., 2004).

Various recent studies were devoted to the genetic and pathogenic variability of $M$. phaseolina. Significant advances in molecular detection and differentiation of $M$. phaseolina isolates have been achieved using restriction fragment length polymorphism (RFLP), random amplified polymorphic DNA (RAPD) and amplified fragment length polymorphism (AFLP) analysis. So far, none of these methods have however been able to differentiate isolates of $M$. phaseolina from specific hosts or geographic locations. The lack of a strong correlation between genotype and geographical origin suggests a high diversity level within and among the population of M. phaseolina (Jana et al., 2005). Nevertheless, developed a single RAPD primer OPA-13 that distinguishes isolates of $M$. phaseolina from soybean, sesame, groundnut, chickpea, cotton, common bean, okra and 13 other hosts and this could be useful as taxonomic marker for population studies.

\section{Survival and transmission}

The pathogen was reported first time to be seed borne in soybean in Illinois. Later it was reported to be seed borne in mungbean, groundnut, sesamum, sorghum and cowpea (Nath and Neergard, 1970; Nobel and Richardson, 1986). Kaushik et al. (1987) reported 2.2-15.7 per cent seed infection by Rhizoctonia bataticola (M. phaseolina) in cultivars of Vigna radiata. Sheikh and Ghaffar (1978) reported that Macrophomina phaseolina persisted in soil in the form of black sclerotia, produced in large number in infected host tissue, subsequently dispersed in soil during tillage operations. Agrawal (1993) reported the role of seed borne and soil borne transmission of Macrophomina phaseolina in Vigna radiata. Abawi and Pastor Corrales 
(1990) reported internal and external seed borne nature of $M$. phaseolina on in seed coat and cotyledons tissues of beans (Phaseolus vulgaris). They further observed that transmission of the $M$. phaseolina from seed to seedling causes 7-15 per cent seed rot and 51-67 per cent seedling mortality in mungbean. Sandhu and Singh (1998) found that seeds infected with $M$. phaseolina act as an important source of primary inoculum to cause charcoal rot in cowpea, in new areas, they also reported that the pathogen involved in the seed coat, cotylendone, plumule and radicle thus causing pre-emergence rot. Sharma and Singh (2000) observed 0.538 per cent seed infection by Rhizoctonia bataticola in mungbean from Rajasthan. Singh and Kumar (2002) reported that $M$. phaseolina (Rhizoctonia bataticola) is an important seed and soil borne pathogen, caused dry root rot and leaf blight of urd bean (Vigna mungo). They observed that the pathogen was invariably present in the seed coat and in the cotyledons of infected seeds, further recorded that pathogen survive in infective state up to twenty month in seeds transmitted to seedlings by local contact. Grover and Sakhuja (1981) reported that the Rhizoctonia bataticola causing leaf blight of mung bean was externally seed borne. Arya et al. (2004) studied the location and transmission of seed borne inoculum of Macrophomina phaseolina in soybean and concluded that the fungi lies as hyphae and sclerotia in all three layers (Palisade, hypodermis and alurama) of seed coat as inter and interacellular mycelium and as sclerotia in cotyledons of infected seeds of soybean, they also reported seed and soil borne nature of Macrophomina phaseolina in soybeans.

\section{Symptoms}

On cowpea, disease symptoms are clearly visible from the time of emergence and can be evaluated at various stages of development of the plant. After emergence, symptoms can be observed on the cotyledons as brown to dark spots. However, cotyledons remain on the plant for only a few days, especially when disease occurred. The margins of the cotyledons become bright red, then beige or brown and finally brown to black. Often, they are covered with a grayish mycelium pad bearing scattered sclerotia. This mycelium can be observed also inside entirely colonized cotyledons. At the unifoliate leaf stage, typical symptoms are pinheadsize, charcoal-colored spots which are mostly restricted to the hypocotyl section of the stem, including its subterranean part. Infected spots may expand and develop into large necrotic lesions, usually resulting in death of the plant. M. phaseolina can also infect roots which show necrotic. On adult plants, M. phaseolina causes lesions on stems, spikes, pods and seeds. On stems, lesions are beige and appear at the ramification point of the lateral secondary branches. Colonized tissues become gray and covered with abundant minute black punctuations. Initially these punctuations are immersed, becoming gradually more prominent. From pod peduncles, the fungus spreads to the pods and invades grains. However, necrotic lesions may appear anywhere on the pods. Infected green pods are initially blue-green and then turn brown to reddish. When infection occurs on mature, dry pods, they become white to gray and are covered with locally or widely distributed black bodies on the pod. The fungus penetrates the pod and grains, inducing diverse symptoms depending on tissue infestation level. Early infested grains abort or become empty and dry. The affected parts of the pod become narrow or shrunken deformed and thin when damaged grains are located at the pod tip. The most striking symptom is the sudden wilting and drying of the whole plant, most of the leaves remaining green. The stem and branches are then covered with black bodies and give the charcoal or ashy appearance of dead plants. Withering can be observed from seedling to maturing stage and is the result of necrosis of roots, stems and mechanical plugging of xylem vessels by microsclerotia, but also by toxin production and enzymatic action. Factors affecting the infection and severity of the charcoal rot disease root infection are affected by growth stage and environment. However, there are also reports where a high moisture holding capacity $(40-50 \% \mathrm{MHC})$ resulted in greater $M$. phaseolina colonization on peanut (Husain and Ghaffar, 1995). In white clover, M. phaseolina also tends to be associated with higher final densities of the plant pathogenic nematodes Meloidogyne trifoliophila, Helicotylenchus dihystera and Heterodera trifolii (Zahid et al., 2002). In contrast, in a pot experiment the simultaneous addition of $M$. phsaeolina and Meloidogyne javanica resulted in reduced nematode galls, which was ascribed to the effect of toxic metabolites on the nematode produced by the fungus (Gupta and Mehta, 1989). Many studies have demonstrated the lack of consistent correlation between the severity of host infection and charcoal rot incidence. Visible symptoms of the disease in the field are most apparent under conditions that reduce plant vigor, such as poor soil fertility, high seeding rates, low soil water content high temperatures (Odvody and Dunkle, 1979; Mihail, 1989) and root injury (Canaday et al., 1986). The timing of host reproduction is another factor that has a strong influence on charcoal rot development. In Euphorbia lathyris, early flowering plants succumb more rapidly to charcoal rot than later flowering ones (Mihail, 1989). In sorghum, postflowering water-stressed plants showed more severe charcoal rot symptoms than plants without water stress (Diourte et al., 1995). Initial population density of sclerotia in soil was directly correlated with the severity of charcoal rot of soybean and was inversely related to soybean yield. Mihail (1989) found that average symptom expression and mortality increased with increasing soil temperature and that mortality increased markedly after the soil temperature at 5 $\mathrm{cm}$ reached the range of $28-30^{\circ} \mathrm{C}$.

\section{Disease cycle}

M. phaseolina causes seedling blight, root rot and root and stem rot of more than 500 cultivated and wild plant species including economically important crops as soybean, common bean, sorghum, maize, cotton, peanut, cowpea (Diourte et al., 1995). Softwood forest trees (Abies, Pinus, 
Pseudotsuga) (McCain and Scharpf, 1989), fruit trees (Citrus spp., Cocoa nucifera, Coffea spp.) and weed species (Songa and Hillocks, 1996) are also hosts of the pathogen. The fungus was reported in North and South America, Asia, Africa and Europe. However, it is economically more important in subtropical and tropical countries with a semi-arid climate (Wrather et al., 2001). M. phaseolina produces sclerotia in root and stem tissues of its hosts which enable it to survive adverse environmental conditions. In PDA, pycnidia are not produced except under some specific incubation conditions (Gaetán et al., 2006) and only sometimes in host crops and their importance in the epidemiology of the fungus likely depends on the host involved as well as the fungal isolate. On cowpea, pycnidia are produced at the end of the rainy season, but their epidemiological significance seems minor. On the contrary, in jute crops, pycnidiospores produced on early infected stem and leaf tissues have been reported to be responsible for secondary spread of the disease (Anonymous, 1940). Microsclerotia in soil, infected seeds or host tissues serve as primary inoculum. Root exudates induce germination of microsclerotia and root infection of hosts. The infective hyphae enter into the plant through root epidermal cells or wounds. During the initial stages of pathogenesis, the mycelium penetrates the root epidermis and is restricted primarily to the intercellular spaces of the cortex of the primary roots. As a result, adjacent cells collapse and heavily infected plantlets may die. At flower onset, the fungal hyphae grow intracellularly through the xylem and form microsclerotia that plug the vessels and disrupt host cells. The infected plants show necrotic lesions on stems, branches and peduncles. From pod peduncles, the fungus spreads to the pods and invades grains. Heavily infected plants die prematurely due to the production of fungal toxins e.g. phaseolinone (Bhattacharya et al., 1994) and production of fungal mycelia that plugs host vessels. In soybean, formation of microsclerotia is conditioned by flowering and pod setting and may be indicative of initiation of death of the host. After plant death, colonization by mycelia and formation of sclerotia in host tissue continue until tissues are dry. The mycelium and microsclerotia produced in infected plant material, including plant residues are the means of propagation of the pathogen. Microsclerotia in soil, host root and stems are the main surviving propagules. After decay of root and plant debris, microsclerotia are released into the soil. They are distributed generally in clusters at the soil surface and are localized mainly at a depth of $0-20 \mathrm{~cm}$ (Campbell and van der Gaag, 1993).

\section{Epidemiology}

M. phaseolina survives as microsclerotia in the soil and on infected plant debris. The microsclerotia serve as the primary source of inoculum and have been found to persist within the soil up to three years. The microsclerotia are black, spherical to oblong structures that are produced in the host tissue and released in to the soil as the infected plant decays. These multi-celled structures allow the persistence of the fungus under adverse conditions such as low soil nutrient levels and temperature above $30^{\circ} \mathrm{C}$. Sclerotial survival is greatly reduced in wet soils surviving no more than 7 to 8 weeks and mycelium no more than 7 days. Seeds may also carry the fungus in the seed coat. Infected seed do not germinate or produce seedlings that die soon after emergence.

Germination of the microsclerotia occurs throughout the growing season when temperatures are between 28 and $35^{\circ} \mathrm{C}$. Microsclerotia germinate on the root surface, germ tubes form appresoria that penetrate the host epidermal cell walls by mechanical pressure and enzymatic digestion or through natural openings. The mechanical plugging of the xylem vessels by microsclerotia, toxin production, enzymatic action and mechanical pressure during penetration lead to disease development. The population of $M$. phaseolina in soil will increase when susceptible hosts are cropped in successive years and can be redistributed by tillage practices.

\section{Management strategies}

Most of the described control methods aim to reduce the number of sclerotia in soil or to minimize the contact of the inoculum and the host.

\section{Soil solarization}

The concept of managing soil borne pathogens has now changed. In past, control of these pathogens concentrated on eradication. Later it has been realized that effective control could be achieved by interrupting the disease cycle, plant resistance or the microbial balance leading to disease reduction below the economic injury level, rather than absolute control. The integrated pest management concept encompasses many elements. The soil micro fauna is the most active component in the soil system, assuring the main role in soil biogeochemical cycles. Soil solarization for soil disinfestations has been well established and demonstrated under experimental or commercial conditions in a number of countries.

Soil solarization can be a cost-effective method for management of soilborne diseases, especially for organic growers as it does not demand any special skill and technology. Even though soil solarization is a cost-effective method, it takes a relatively long period of time to work and is solely dependent upon climatic conditions; therefore its application in crop production is limited.

Puri (2016) reported that soil solarization has been demonstrated to control diseases caused by many fungal pathogens such as Rhizoctonia solani, Macrophomina phaseolina, Fusarium spp., Pythium spp., Phytophthora spp., Verticillium spp., Bipolaris sorokiniana, Plasmodiophora brassicae, Sclerotium rolfsii etc.

\section{Bioagents}

Biocontrol involves harnessing disease-suppressive microorganisms to improve plant health. Disease 
suppression by biocontrol agents is the sustained manifestation of interactions among the plant, the pathogen, the biocontrol agent, the microbial community on and around the plant and the physical environment.

Ushmaliniet et al. (1997) reported antagonistic activity of $T$. viride and $T$. harzianum against $M$. phaseolina causing charcoal rot of cowpea and mungbean. Majumadar et al. (1996) found antagonistic activity of Trichoderma viride, T. harzianum and Bacillus subtilis against $M$. phaseolina incitant of leaf blight of mothbean, they further reported that T. harzianum inhibited maximum growth of pathogen. In pot condition T. harzianum proved superior to other organism in reducing pre and post emergence root rot. Kumar and Kumar (2000) reported that $T$. viride used as seed treatment completely eliminated seed borne infection of Rhizoctonia bataticola (M. phaseolina) in pigeonpea. Patel and Anahosur (2001) observed that Trichoderma harzianum showed mycoparasitism against Macrophomina phaseolina tested in in vitro. Dubey and Patel (2002) reported that T. viride at $6 \mathrm{~g} / \mathrm{kg}$ seed effectively reduced plant mortality caused by $R$. solani in mung bean. Manczinger et al. (2002) reported that the members of the genus Trichoderma ( $T$. viride, T. polysporum and T. harzianum) have a strong antagonistic activity against soil borne plant parasitic fungi. Bhantangar and Bansal (2003) observed that T. polysporum was highly antagonistic against Macrophomina phaseolina Tassi (Goid) causing dry root rot in cowpea. Wang et al. (2003) reported Pseudomonas fluroescens reduced the severity of Rhizoctonia solani both in vivo and in vitro conditions in pea. Sajeena et al. (2004) tested four biocontrol agents in M. phaseolina infested soil in pots for suppression of dry root rot pathogen in black gram and reported that seed treatment with Trichoderma viride and Pseudomonas fluroescens individually as well as in combination were found to be more affected than soil application.

\section{Effective oils and phytoextract}

Essential oils and plant extracts contain a multitude of bioactive substances against fungi, bacteria and nematodes. In plant pathology research, botanicals are commonly used in their raw state. Without any type of formulation, bioactive compounds of plants can be degraded and volatilized rapidly under field conditions.

Behura et al. (2000) tested fungicidal activity of leaf and rhizome oil of Curcuma longa against Rhizoctonia solani in rice and observed the leaf oil showed the greatest inhibition of Rhizoctonia solani. El-Sherbieny et al. (2002) tested oils of sweet basil (Ocimum basilicum), thyme (Thymus vulgaris), mint (Mentha piperita) and cumin (Cuminum cyminum) in in vitro against Macrophomina phaseolina, Fusarium solani and Rhizoctonia solanicausing cotton seedling damping off and observed that mycelial growth was completely inhibited with cumin and mint oil. Prakash et al. (2001) tested oils of Collistemon lanceolatus, Citrus medica and Ocimum canum by poisoned food technique, against Rhizoctonia solani, the incitant of damping off disease of tomato and chilli (Capsicum annum) and concluded that Citrus medica, Eucalyptus alba and $O$. canum was completely inhibited the growth of the fungus. Lambat et al. (2004) tested efficacy of lemongrass (Cymopogon spp.) and eucalyptus oil (Eucalyptus spp.) at 0.02-0.06 per cent Concentration against F. oxysporum and M. phaseolina and observed 100 per cent growth inhibition of $M$. phaseolina with lemongrass oil at 0.06 per cent oncentration. Thakare et al. (2003) tested efficacy of oil of six medicinal plants viz., mentha, ocimum, lemongrass, citronella, turmeric and palmarosa under in vitro condition for their antifungal activity against growth of Rhizoctonia bataticola and reported that mentha, palmarosa, lemongrass and citronella oil exhibited $100 \%$ inhibition of Rhizoctonia bataticola at 1 and 2 per cent concentration. Kumar (2003) reported that application of heeng (Asafoetida) powder and FYM are effective against rotting of bottle guard.

\section{Chemicals}

Chemical control is an effective method of controlling some soilborne diseases in agricultural crops. As non-chemical alternative methods can be time-consuming and less effective against soilborne plant pathogens. Fungicides of various types have been successful in controlling most major diseases in growing crops intended for market. The commercially important diseases are (in an order of relative importance) seed-borne diseases; soil borne diseases, powdery mildews, cereal stem diseases, rusts and smuts.

Upmanyu et al. (2002) studied the efficacy of fungicides and bioagents as seed treatment and foliar spray for the management of root rot and web blight of French bean caused by $R$. solani and concluded that Tebuconazole + T. virens (ST) + carbendazim (FS), was found effective in reducing the disease incidence. Sharma and Gupta (2003) reported that Trichoderma harzianum and ethanol extracts of Ocimum sanctum were found highly effective in inhibiting the mycelial growth of $R$. solani under in vitro condition. Seed dipping with 4 per cent ethanol extract of $O$. sanctum was found effective in checking the pre and post emergence root rot of french bean. Murthy et al. (2003) studied the efficacy of fungicides and bioagent as seed treatment against Macrophomina phaseolina in green gram and reported that carbendaziam $(0.2 \%)$ and $T$. harzianum was most effective in controlling the seed borne pathogen. Kumar and Jain (2004) reported that seeds treated by carbendazim (bavistin$2.0 \%$ ), tebuconazole (raxil, $2.0 \%$ ), thiophanate-methyl (topsin-M 45, 2.5\%) and thiram (thiram, 2.5\%) was effective against blight and root rot diseases caused by Macrophomina phaseolina in clusterbean. They further observed that raxill and indofil M-45 were found inferior among all the treatments. Seed treatment with topsin-M, bavistin, indofil-M-45 (each $2.0 \mathrm{~g} / \mathrm{kg}$ seed) eliminated the Macrophomina phaseolina from infected seeds of urdbean (Vigna mungo) Singh and Kumar (2002).

Rathore (2006) tested as seed treatment and foliar spray carbendazim, topsin M-70, captan, thiram, mancozeb, copper oxychloride against root rot and leaf blight (Macrophomina phaseolina) and leaf spots (Cercospora 
canesens) of greengram (Vigna radiata) and observed that seed treatment with carbendazim (bavistin 50 WP @ 2 g/ $\mathrm{kg}$ seeds) was very effective as it recorded the minimum disease incidence of root rot (14\%), topsin M 70 WP-2 $\mathrm{g} / \mathrm{kg}$ seed treatment was at par with carbendazim. Untreated plots recorded maximum disease incidence (35\%). Gupta and Sharma (2007) reported compatibility of biocontrol agents with fungicides. Carbendazim and biocontrol agents Trichoderma viride, T. harizianum were found effective under in vitro and pot condition.

\section{REFERENCES}

Abawi, G.S. and Pastor-Corrales, M.A. (1990). Seed transmission and effect of fungicide seed treatments against Macrophomina phaseolina in dry edible beans. Turrialba. 40(3): 334339.

Agarwal, S.C. (1993). Transmission of leaf blight pathogen in urdbean. Indian J. Pulses Res. 6(2): 217-219.

Anonymous (1940). Indian Central Jute Committee. Annual Report of the Agric. Res. Sch. 50 p.

Arya, V.K., Vishunaval, K. and Negi, H. (2004). Detection, location and Transmission of seed borne inoculum of Macrophomina phaseolina in charcoal rot in soybean. J. Mycol. PI. Pathol. 34(2): 233-237.

Behura, C., Ray, P., Rath, C.C., Mishra, R.K., Ramachandraiah, O.S. and Charyulu, J.K. (2000). Antifungal activity of essential oils of Curcuma longa against five rice pathogens in vitro. J. Essential Oil Bearing PI. 3(2): 79-84.

Bhantangar, K. and Bansal, R.K. (2003). Trichoderma polysporum a new antagonist against Macrophomina phaseolina causing dry root rot in cowpea. J. Mycol. PI. Path. 33(2): 331.

Bhattacharya, D., Dhar, T.K., Siddiqui, K.A.I. and Ali, E. (1994). Inhibition of seed germination by Macrophomina phaseolina is related to phaseolinone production. J. Appl. Bacteriol. 77: 129-133.

Campbell, C.L. and Van der Gaag, D.J. (1993). Temporal and spatial dynamics of microsclerotia of Macrophomina phaseolina in three fields in North Carolina over four to five years. Phytopathology. 83: 1434-1440.

Canaday, C.H., Helsel, D.G. and Wyllie, T.D. (1986). Effects of herbicide-induced stress on root colonization of soybeans by Macrophomina phaseolina. Plant Dis. 70: 863-866.

Diourte, M., Starr, J.L., Jeger, M. J., Stack, J.P. and Rosenow, D.T. (1995). Charcoal rot (Macrophomina phaseolina) resistance and the effects of stress on disease development in sorghum. Plant Pathol. 44: 196-202.

Dubey, S.C. and Patel, B. (2002). Mass multiplication of antagonists and standardization of effective dose for management of web blight of urd and mung bean. Indian Phytopath. Pp: 338-341.

El-Sherbieny, S.N., Zakey, W.H. and Abdel-Ghafor, S.M. (2002). Antifungal action of some essential oils against fungi causing cotton seedling damping off disease. Annals of Agril. Sci. Cario. 17 (3): 1009-1020.

Fuhlbohm, J., Ryley, M.J., Aitken, E.A.B. (2013). Infection of mungbean seed by examining infection of soybean roots by Macrophomina phaseolina. Physiol. Mol. Plant Pathol. 74: 201-204.
Gaetán, S.A., Fernandez, L. and Madia, M. (2006). Occurrence of charcoal rot caused by Macrophomina phaseolina on canola in Argentina. Plant Dis. 90: 524.

Ghosh, R., Tarafdar, A., Sharma, M. (2017). Rapid and sensitive diagnoses of DRR pathogen of chickpea [Rhizoctonia bataticola (Taub.) Butler] using loop-mediated isothermal amplification assay. Sci. Rep. 7. Article number: 42737.

Goidanich, G. (1947). A Revision of the genus Macrophomina Petrak. type species: M.P. (Tassi) G. Goid. n. comb. M.P. (Maubl.) Ashby. Ann. Sper. Agr. N. S. I. 3: 449-461.

Grover, R.K. and Sakhuja, P.K. (1981). Some pathological studies on Rhizoctonia bataticola leaf blight of mungbean. Indian Phytopath. 34: 24-29.

Gupta, D.C. and Mehta, N. (1989). Interaction studies between different levels of Meloidogyne javanica and Rhizoctonia spp. on mung bean [Vigna radiate (L.) Wilczek.]. Indian J. Nematol. 19: 138-143.

Gupta, V.K. and Sharma, K. (2007). Integration of chemical and biocontrol agents for managing while root rot of apple. Acta Horticulture, I.S.H.S.www.actahort.org.

Husain, T. and Ghaffar, A. (1995). Effect of soil moisture on the colonization of Macrophomina phaseolina on roots of chickpea. Pak. J. Bot. 27: 221-225.

lqbal, U. and Mukhtar, T. (2014). Morphological and pathogenic variability among Macrophomina phaseolina isolates associated with mungbean (Vigna radiata L.) Wilczek from Pakistan. Sci. World J. 1-9. Article ID 950175.

Jana, T., Singh, N.K., Koundal, K.R. and Sharma, T.R. (2005). Genetic differentiation of charcoal rot pathogen, Macrophomina phaseolina, into specific groups using URP-PCR. Can. J. Microbiol. 51: 159-164.

Kaushik, C.D., Chand, J.N. and Saryavir (1987). Seed borne nature of Rhizoctonia bataticola causing leaf blight of mungbean. Indian J. Mycol. PI. Pathol. 17(2) : 153-157.

Khan, A.N., Shair, F., Malik, K., Hayat, Z., Khan, M.A., Hafeez, F.Y. and Hassan, M.N. (2017). Molecular identification and genetic characterization of Macrophomina phaseolina isolates causing pathogenicity on sunflower and chickpea. Front. Microbiol. https://doi.org/10.3389/fmicb.2017.01309.

Kumar, A. (2003). Role of traditional practices and farmer's innovations in sustainable plant disease management. Asian Agrihistory, pp. 830-831.

Kumar, P.A. and Kumar, K. (2000). Bio-control of seed borne fungal pathogens of pigeonpea [Cajanus cajan (L.) Mill sp.]. Annals PI. Prot. Sci. 8 (1): 30-32.

Kumar, R.K. and Jain, S.C. (2004). Macrophomina phaseolina in clusterbean (Cyamopsis tetragonoloba) seed and its control. J. Mycol. PI. Pathol. 34 (3): 833-835.

Lambat, Pretty., Zore, G.B., Surwase, B.S. and Karappayil, S.M. (2004). Broad spectrum antifungal activity in essential oils from lemongrass and eucalyptus. J. Mycol. PI. Pathol. 34(2): 545-547.

Majumdar, V.L., Jat, J.R. and Gour, H.N. (1996). Effect of bio-control agents on the growth of Macrophomina phaseolina, the incitant of blight of mothbean. Indian J. Mycol. PI. Path. 26: 202-203.

Manczinger, L., Antal, Z. and Kredics, L. (2002). Ecophysiology and breeding of mycoparasitic Trichoderma studies (a review). Acta Micro. et. Immun. Hungarica. 49(1) : 1-14. 
Root Rot Disease Incited by Macrophomina phaseolina in Arid Legumes and their Management: A Review

McCain, A.H. and Scharpf, R.F. (1989). Effect of inoculum density of Macrophomina phaseolina on seedling susceptibility of six conifer species. Eur. J. For. Pathol. 19: 119-123.

Mihail, D.J. (1989). Macrophomina phaseolina: Spatio-temporal dynamics of inoculum and of disease in a highly susceptible crop. Phytopathology. 79: 848-855.

Murthy, K., Niranjana, S.R. and Selty, H.S. (2003). Effects of chemical fungicides and biological agent on seed quality improvement in pulses. Seed Res. 31(1): 121-124.

Nath, R.S.B. and Neergard, P. (1970). Seed Borne Fungi of Mungbean [Phaseolus aureus (Roxb.)] from India and their Significance. Proc. Int. Seed. Test. Assoc. 35 : 225-241.

Nobel, M. and Richardson, M.J. (1986). An Annotated List of Seed Borne Disease. Sec. Ed. Proc. Int. Seed. Test. Assoc. 33: $1-91$.

Odvody, G.N. and Dunkle, L.D. (1979). Charcoal stalk rot of sorghum: Effect of environment on host-parasite relation. Phytopathology. 69: 250-254.

Patel, S.T. and Anahosur, K.H. (2001). Potential antagonism of Trichoderma harzianumagainst Fusarium spp., Macrophomina phaseolina and Sclerotium rolfsii. J. Mycol. PI. Pathol. 31(3): 365.

Prakash, O.M., Pandey, V.N. and Pant, D.C. (2001). Fungitoxic properties some essential oils from higher plants. Madras Agril. J. 88: (1-3): 73-77.

Puri S. (2016). Eco-friendly management strategies for soil borne plant pathogens. Internat. J. Adv. Res. Biol. Sci. 3(1): 69-75.

Purkayastha, S., Kaur, B., Dilbaghi, N. and Chaudhury, A. (2004). Cultural and pathogenic variation in the charcoal rot pathogen from clusterbean. Ann. Agri. Biol. Res. 9: 217221.

Ramezani, H. (2008). Biological control of root-rot of eggplant caused by Macrophomina phaseolina. Am. Eurasian J. Agric. Environ. Sci. 4, 218-220.

Rathore, B.S. (2006). Management of diseases of green gram with fungicides. Indian J. Mycol. PI. Path. 36(2): 138-141.

Reyes-Franco, M.C., Hernández-Delgado, S., Beas-Fernández, R., Medina, Fernández, M., Simpson, J. and Mayek-Pérez, N. (2006). Pathogenic variability within Macrophomina phaseolina from Mexico and other countries. J. Phytopathol. 154: 447-453.

Sajeena, A. Rajan, F. Salal., Seetharaman, K. and Mohan Babu, R. (2004). Evaluation of biocontrol agents against dry root rot of blackgram (Vigna mungo). J. Mycol. PI. Pathol. 34 (2): 341-344.

Saleh, A., Ahmed, H., Todd, T., Travers, S., Zeller, K. and Leslie, J. (2010). Relatedness of Macrophomina phaseolina isolates from tallgrass prairie, maize, soybean and sorghum. Mol. Ecol. 19: 79-91.
Sandhu, A. and Singh, R.D. (1998). Role of seed borne inoculum in development of charcoal rot of cowpea. J. Mycol. PI. Pathol. 28: 193-195.

Sharma, K. and Singh, T. (2000). Seed and seedling infection of Rhizoctonia bataticola in Vigna radiata. J.. Mycol PI. Pathol. 30(1): 15-18.

Sharma, M. and Gupta, S.K. (2003). Ecofriendly methods for the management of root rot and web blight (Rhizoctonia solani) of French bean. J. Mycol. PI. Pathol. 33 (3): 345361.

Sheikh, A.H. and Gaffar, A. (1978). Relation of sclerotial inoculum density and soil moisture to infection of field crops by Macrophomina phaseolina. Pak. J. Bot. 11: 185-189.

Singh, J. and Kumar, K. (2002). Location, survival, transmission and control of seed borne, Macrophomina phaseolina causing dry root rot and leaf blight in urdbean. Annals of PI. Prot. Sci. 10 (1): 111-113.

Songa, W. and Hillocks, R.J. (1996). Legume hosts of Macrophomina phaseolina in Kenya and effect of crop species on soil inoculum level. J. Phythopathol. 144: 387-391.

Sundaramoorthy, S., Murugapriya, E., Maharaja, L.G.J. and Alice, D. (2013). Induction of systemic resistant in green gram against leaf blight caused by Macrophomina phaseolina (Tassi.) Goid. Afr. J. Microbiol. Res. 7: 3976-3982.

Suriachandraselvan, M., Aiyyanathan, K.E.A. and Vimala, R. (2005). Host range and cross inoculation studies on Macrophomina phaseolina from sunflower. Madras Agric. Res. J. 92: 238240.

Thakare, A.R., Wankhade, S.G., Somani, R.B. and Raut, B.T. (2003). Growth inhibition in Rhizoctonia bataticola and Xanthomonas axonopodis Pv. malvacearum by herbal oil. J. Spice Aro. Crops. 12(1): 83-85.

Upmanyu, S., Gupta, S.K. and Shyam, K.R. (2002). Innovative approaches for the management of root rot and web blight (Rhizoctonia solanı) of French bean. J. Mycol. PI. Pathol. 32(3): 317-331.

Ushamalinet, C., Rajappan, K. and Kousalya, G. (1997). Management of charcoal rot of cowpea using bio control agents and plant products. Indian Phytopath. 50: 504-507.

Wang, H., Hwany, S.F., Chang, K.F., Turnbull, G.D. and Howard, R. (2003). Suppression of important pea disease by bacterial antagonists. Bio-control. 48 (4) : 447-460..

Wrather, J.A. anderson, T.R., Arsyad, D.M., Tan, Y., Ploper, L.D., Porta-Puglia, A., Ram, H.H. and Yorinori, J.T. (2001). Soybean disease loss estimates for the top 10 soybean producing countries in 1998. Can. J. Plant Pathol. 23: 115-121.

Zahid, M.I., Gurr, G.M., Nikandrow, A., Hodda, M., Fulkerson, W.J. and Nicol, H.I. (2002). Effects of root- and stolon-infecting fungi on root-colonizing nematodes of white clover. Plant Pathol. 51: 242-250. 